\title{
Kinetic and Transesterification Properties of Lipase from Sprouted Melon (Cucumeropsis manni) Seeds
}

\author{
*OSEMWENKHAE, PO; UADIA, PO
}

\author{
Department of Biochemistry, Faculty of Life Sciences, University of Benin, Benin City, Nigeria \\ *Corresponding Author Email: osaretin.osemwenkhae@uniben.edu; Tel: +2348082429389
}

\begin{abstract}
Crude lipase (acetone powder) was extracted from freshly sprouted melon seeds (Cucumeropsis manni). The activity, kinetic properties (effect of time, $\mathrm{pH}$, and enzyme and substrate concentration, respectively) as well as the ability of the crude lipase to catalyze the production of methyl esters (biodiesel) were examined. The enzyme activity was determined using $\mathrm{n}$-hexane as the solvent (1:2 v/w solvent: substrate ratio) and the transesterification product was analyzed by HPLC. A linear relationship was observed between reaction time and rate of lipolysis with the optimal activity at $2 \mathrm{hr}$ of incubation. Furthermore, the lipase was optimally active at acid $\mathrm{pH} 5$ and lipolysis was achieved optimally when the amount of enzyme was $2.0 \mathrm{~g}$. Rate of lipolysis was observed to increase linearly at concentrations up to $5.0 \mathrm{~g}$ of substrate above which a drop in the rate, with no apparent decrease in activity, was observed. The $\mathrm{K}_{\mathrm{m}}(6.25 \mathrm{~g})$ and $\mathrm{V}_{\max }(13.33 \% \mathrm{FFA} / \mathrm{hr})$ were also determined. Analysis of the transesterification product yielded $0.61 \%$ alkyl ester, $0.81 \%$ FFA, 93.17\% TAG, 4.15\% 1, 3-DAG and 1.26\% 1, 2-DAG while transesterification efficiency was determined to be at $0.588 \%$. Biodiesel (alkyl esters) prepared with the crude lipase was had a density of $0.872 \mathrm{~g} / \mathrm{mL}$ while its cloud and pour points were $22^{\circ} \mathrm{C}$ and $12^{\circ} \mathrm{C}$, respectively. The results from this research showed that an active lipase was isolated from sprouted melon seeds. However, the fuel properties of the biodiesel produced did not meet international transportation fuel standards. In order to be used industrially, better reaction conditions need to be established for the lipase.
\end{abstract}

\section{DOI:https://dx.doi.org/10.4314/jasem.v25i7.34}

Copyright: Copyright (C) 2021 Osemwenkhae and Uadia. This is an open access article distributed under the Creative Commons Attribution License (CCL), which permits unrestricted use, distribution, and reproduction in any medium, provided the original work is properly cited.

Dates: Received: 09 May 2021; Revised: 12 August 2021; Accepted: 12 September 2021

Keywords: Cucumeropsis manni, Biodiesel, lipsases, transesterification, alkyl esters.

Cucumeropsis mannii Naud syn. Cucumropsis edulis (Hook. F). is a species of melon native to Tropical Africa, West of the Great Rift Valley. It belongs to the Cucurbitaceae family and its common names include 'Ogi' in Edo, 'Egusi' in Yoruba and 'Agushi' in Hausa (Fokou et al., 2005). C. mannii is an herbaceous plant, produces climbing vines up to 4 metres long and are covered in stiff hairs. The fruit is egg-shaped or an elongated ovate shape and cream in colour with green streak. The fruits are indehiscent smooth berries which enclose many seeds (Gwanfogbe et al., 1991). The fruit and white seeds are edible and the seeds are major soup ingredients in Cameroon and Nigeria. The flesh of the fruit is edible but as an item of diet, it appears to be less important than the oily seeds for which the plant is mainly cultivated. C. mannii has an important value in the African traditional societies (Ponka et al., 2005). Also, its seeds are an excellent vermifuge and its oil favours blood circulation. Juice from the fruit mixed with other ingredients is applied in Ghana to the navel of a newborn baby for five days till the cord-relic drops off. C. mannii is an oleaginous seed and its high oil content has been shown by several studies (Martin, 1998; Fokou et al., 2004; Achu et al., 2005). Analysis of the fatty composition revealed four main fatty acids viz palmitic acidd, C16:0 (15.5\%), stearic acid, C18:0 (11.3\%), oleic acid, C18:1 (11.8\%) and linoleic acid, C18:2 (60.3\%) and the absence of short-chain fatty acids (Achu et al., 2006). C. mannii is also a good source of unsaturated fatty acids, especially the polyunsaturated fatty acids, with linoleic acid being the most abundant. Its percentage content of linoleic acid is better than that of animal fats (Achu et al., 2006).

Lipases (triacylglycerol acylhydrolase, E.C. 3.1.1.3) are enzymes that catalyze the reversible hydrolysis of glycerol ester bonds. They are widely distributed amongst animals, plants and microorganisms. Under certain circumstances, lipases also catalyze a number of transesterification reactions. In low-water environment, they are excellent tools for the transformation of commercial triglycerides and/or their derivatives, to synthesize a growing range of products of potential industrial interest (Pirozi, 2003). Lipases have been used to produce fatty acids, biosurfactants (Edmundo et al., 1998), lubricant and solvent esters (Hills, 2003), polyesters (Kumar et al., 2000) amides, thiolesters (Gandhi, 1997) and biomodified fats (Neklyudov, 2002). Due to its numerous potential applications, it has been become a subject of intense research. In this context, the search for new lipases, with new and better specificities and the technology for their use, are driving investigations. For most applications, the sources of lipases have been micro-organisms such as mold and yeast. There are at least 35 lipases available commercially, but only a few can be obtained in industrial quantities. Lipases from 
plants have been studied only to a minor extent (Sanders and Petttee, 1974). Germinating oilseeds are being explored as a possible source of lipase for the biotechnological processing of oils and fats (Hassanien and Mukherjee, 1986). Seeds generally contain starch, proteins and triacylglycerols as food reserves for germination. In oil seeds, lipase activity is generally expressed during germination (Lin and Huang, 1983). The utilization of the stored fat is initiated by hydrolysis of triacylglycerols to free fatty acids and glycerol by the lipase. These intermediate products are then converted to sucrose by a long gluconeogenic pathway for supporting plant growth (Huang, 1975; Hulton and Strumpf, 1969). Biodiesel is a name applied to fuels manufactured by the transesterification of renewable oils, fats and fatty acids (Gabroski and Mcermick, 1998). In more specific terms, biodiesel refers to a family of products made from vegetable oils or animal fats and alcohol (methanol or ethanol). These products are called alkyl esters of fatty acids. In recent years, biodiesel has been described as a strong candidate to replace petroleum diesel due to the similarities in their characteristics and the advantages of biodiesel over petroleum diesel (Yousef et al., 2005). This diesel fuel substitute has several advantages viz it is prepared from renewable sources, it solves the problem of agricultural overproduction, it is miscible with fuel in any ratio, it is biologically degradable and the fumes contain smaller amounts of harmful substances (Cvengros and Cvengrosova, 1994). In order for these alkyl esters to be considered as viable transportation fuels, they must meet stringent quality standards, otherwise, they become standard industrial chemicals that are not suitable for diesel applications. Thus, alkyl esters of fatty acids that meet transportation standards are called biodiesels. Transesterification of vegetable oils or animal fats, catalyzed either by a chemical catalyst (acid or base) or biological catalyst (lipases), is the most effective process for the transformation of triglyceride molecules into smaller, straight-chain molecules of alkyl-esters (Noureddini et al., 1998). The most interesting research today is focused on the utilization of lipases for catalyzing the synthesis of simple esters of vegetable oils or other agriculture lipid feedstock with or without the presence of organic solvents. In spite of their potential industrial applications lipase-catalyzed transesterification remains to be adopted commercially on a broad scale due to high catalytic cost and slow reaction rates (Haas, 2004). Germinating oilseeds are being explored as a possible source of lipase for the biotechnological processing of oils and fats (Hassaninen and Mukharjee, 1986) and most of the investigations on lipases have been carried out on oleaginous seeds. However, lipases from plants have been studied only to a minor extent. The aim of this study is to extract, characterize and study the kinetic and transesterification properties of Cucumeropsis mannii lipase, with a view of producing cheaper and effective lipase for the production of biodiesel in future.

\section{MATERIALS AND METHODS}

Chemicals: All solvents (Ethanol, petroleum ether, nhexane, anhydrous sodium sulphate, sodium hydroxide, acetic acid and sodium chloride) were of analytical grade and were product of BDH Chemicals Limited (Poole, England). Methanol, also of analytical grade, was obtained from Fischer Scientific (UK) while acetone, dipotassium hydrogen phosphate, potassium dihydrogen phosphate and sodium acetate were obtained from May and Bakers (Dagemhan, UK).

Plant Materials: Unshelled melon seed (Cucumeropsis mannii) were obtained near the Nigerian Institute for Oil Palm Research (NIFOR) main station, Benin City, Edo State, Nigeria. The Refined Bleached Deodorized (RBD) palm oil used was obtained from the Biochemistry Division, NIFOR.

Seed germination: Unshelled C. mannii seeds were steeped in water for 30 minutes, transferred to a polythene bag and allowed to germinate at room temperature $\left(26 \pm 1^{0} \mathrm{C}\right)$. Germination period was $4-5$ days after which they were harvested and unshelled for enzyme preparation.

Enzyme extraction: Isolation of the lipase as carried out at $4^{0} \mathrm{C}$ according to the method of Muto and Beevers (1974). Briefly, 197g of sprouted, unshelled melon seeds were blended with $200 \mathrm{~mL}$ of cold acetone using a warring blender. The acetone extract was then filtered through a cheese cloth and washed four times with $120 \mathrm{~mL}$ of cold acetone. The residue obtained was air-dried at room temperature to produce the acetone powder (enzyme) which was then kept at $4^{0} \mathrm{C}$ until it was ready for use. The percentage yield of enzyme was calculated as follows:

$$
\% \text { Yield }=\frac{\text { Mass of acetone powder }}{\text { Mass od sprouted melon seed }} \times 100 \%
$$

Assay of enzyme activity: Lipase activity was assayed using a modification of the micrometric method of Khor et al., (1986). The assay mixture contained $5 \mathrm{~g}$ of RBD palm oil (substrate), $2.5 \mathrm{~mL}$ of hexane to solubilize the oil and $1 \mathrm{~g}$ of the crude enzyme. The mixture was incubated at room temperature for $1 \mathrm{hr}$ with continuous stirring. Thereafter, $25 \mathrm{~mL}$ of acetone-methanol $(1: 1 \mathrm{v} / \mathrm{v})$ was added to stop the reaction and to extract the free fatty acids (FFAs) liberated. The FFAs in the mixture were then estimated by adding $50 \mathrm{~mL}$ of neutralizing solvent to the mixture and then titrating against $0.01 \mathrm{M} \mathrm{NaOH}$ to the first permanent pink colour. Activity was expressed as the percentage FFA liberated after $1 \mathrm{hr}$ incubation (Wetter, 1957). Corrections were made for endogenous fatty acid produced (assay mixture 
without substrate) and non-enzymatic fatty acid produced (assay mixture without enzyme preparation). The percentage FFA was calculated according to the equation below:

$$
\% \mathrm{FFA}=\frac{25.6 \times \mathrm{M} \times \mathrm{V}}{\mathrm{W}}
$$

$\mathrm{M}=$ Molarity of $\mathrm{NaOH}$ solution; $\mathrm{V}=$ Volume of $\mathrm{NaOH}$ solution used in $\mathrm{mL}$ (titre value); $\mathrm{W}=$ Weight of substrate

Enzyme activity was then expressed as the percentage of FFA released per hour:

$$
\text { Activity }=\% \mathrm{FFA} / \mathrm{hr}
$$

Effect of time on lipase activity: This was determined by varying the time of incubation of the assay mixture as $0,0.5,1,1.5$ and $2 \mathrm{hr}$ respectively. The assay mixture still contained $5 \mathrm{~g}$ of substrate (RBD palm oil), $2 \mathrm{~g}$ of acetone powder (crude enzyme extract) and 2.5 $\mathrm{mL}$ of $\mathrm{n}$-hexane at the same temperature (room temperature), with continuous stirring. Lipase activity was determined as described above.

Effect of amount of substrate on lipase activity: The dependence of the rate of lipolysis on substrate concentration was determined by assaying lipase activity with varying concentrations $(1 \mathrm{~g}, 3 \mathrm{~g}, 5 \mathrm{~g}, 7 \mathrm{~g}$ and $10 \mathrm{~g}$ ) of substrate in $2.5 \mathrm{~mL}$ of $\mathrm{n}$-hexane. The assay was carried out at the optimum $\mathrm{pH}$ of the lipase $(\mathrm{pH}$ 5.0) and incubated at room temperature for $1 \mathrm{hr}$ with continuous stirring. Enzyme activity was determined for each substrate concentration as described above.

Effect of amount of enzyme on lipase activity: The effect of varying concentration of enzyme on the rate of lipolysis was determined by varying the quantity of the crude acetone powder lipase as 0.5, 1.0, 1.5 and 2.0 grammes. Each of these were used in the assay mixture with $5 \mathrm{~g}$ of substrate in $2.5 \mathrm{~mL}$ of $\mathrm{n}$-hexane. The mixture was incubated at room temperature for 1 hour with continuous stirring and enzyme activity was done as described above.

Effect of pH on lipase activity: Acetate buffer ( $\mathrm{pH} 3-$ 5) and phosphate buffer ( $\mathrm{pH} 6-10)$ were used for this assay. Five millilitres $(5 \mathrm{~mL})$ of each buffer of a particular $\mathrm{pH}$ were added to $5 \mathrm{~g}$ of substrate, $1 \mathrm{~g}$ of crude enzyme preparation and $2.5 \mathrm{~mL}$ of $\mathrm{n}$-hexane. The mixture was incubated at room temperature for 1 $\mathrm{hr}$ with continuous stirring. The activity was then determined for each $\mathrm{pH}$ value.

Enzymatic transesterification (alcoholysis): Transesterification reaction was carried out using the lipase extracted from sprouted $C$. mannii seeds as the biocatalyst. The enzyme-catalyzed reactions were initiated by adding the lipase $(10 \%$ wt./wt. of substrate) in the ratio of 1 mole (RBD palm oil) +4 moles (Alcohol) $+10 \%$ (wt. of oil) enzyme.

Methanol was added at various time intervals. This was done by dividing the total volume of methanol to be used into four volumes and dispensing each part at $0,2,4$ and $6 \mathrm{hr}$ of reaction respectively (Abigor et al., 2000). The transesterification reaction, which was done in duplicate, was carried out in a Clifton Shaker water bath at $250 \mathrm{rpm}$ and $40^{\circ} \mathrm{C}$ for $8 \mathrm{hr}$. At the end of the first $2 \mathrm{hr}$ of incubation, $0.4 \%$ (wt. of oil) of molecular sieve was added to the reaction mixture. Upon completion of the transesterification process, the mixture (biodiesel) was diluted with 4 volumes of hexane:ether $(1: 1 \mathrm{v} / \mathrm{v})$ solution and washed with 2 volumes of saturated sodium chloride and well shaken in a separating funnel. The upper organic layer was taken while the lower aqueous layer extracted with another 4 volumes of hexane:ether $(1: 1 \mathrm{v} / \mathrm{v})$ solution. The combined organic layers were dried over anhydrous sodium sulphate, filtered through glass wool and then de-solventized in a stream of nitrogen.

Determination of the Cloud Point, Pour Point and Relative density of biodiesel: Cloud point and Pour point temperatures and the relative density of the biodiesel produced were measured using standard ASTM D97-96a, ASTM D2500 and ASTM D287 methods, respectively.

Analysis of the transesterification product: To determine the ability of the crude lipase to convert RBD palm oil to its alkyl ester (biodiesel) with ethanol, the transesterification product was analyzed by HPLC at a facility in the US Department of Agriculture, USA.

\section{RESULTS AND DISCUSSION}

The result obtained in this study revealed lipase activity in sprouted seeds of Cucumeropsis mannii seeds. Most investigations on plants lipases have been carried out on oleaginous seeds in which the activity is generally found to become prominent upon germination (Hassanien and Mukherjee, 1986). The kinetic parameters determined for the oilseed lipase include effect of varying amount of enzyme with a constant amount of substrate, effect of varying the time of incubation, effect of $\mathrm{pH}$ and the effect of varying amount of substrate on lipase activity. The result of varying amount of enzyme with a constant amount of substate when plotted was linear and incremental (Fig 1). This is in agreement with the findings of Hassanien and Mukhrjee (1986) as well as Sanders and Pattee (1975), which showed a linear relation was evident between varying amount of enzyme in the presence of a fixed substrate amount. In this study, the result shows that the lipolysis of $5 \mathrm{~g}$ of oil could be achieved optimally at a $2.0 \mathrm{~g}$ amount of enzyme. Increasing the amount of enzyme from $0.5 \mathrm{~g}$ to $1.5 \mathrm{~g}$ caused a steady increase in activity signifying a steady liberation of 
free acid. Beyond this, a very high rate of lipolysis was observed as indicated by the increase in activity.

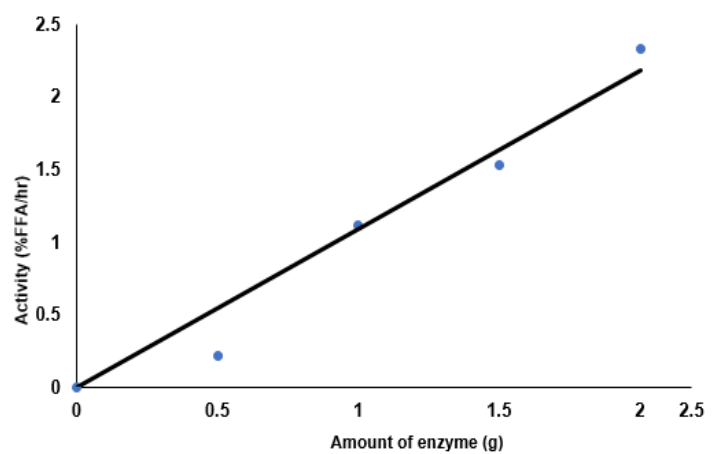

Fig 1: Effect of varying amount of enzyme (g) on lipase activity $(\% \mathrm{FFA} / \mathrm{hr})$

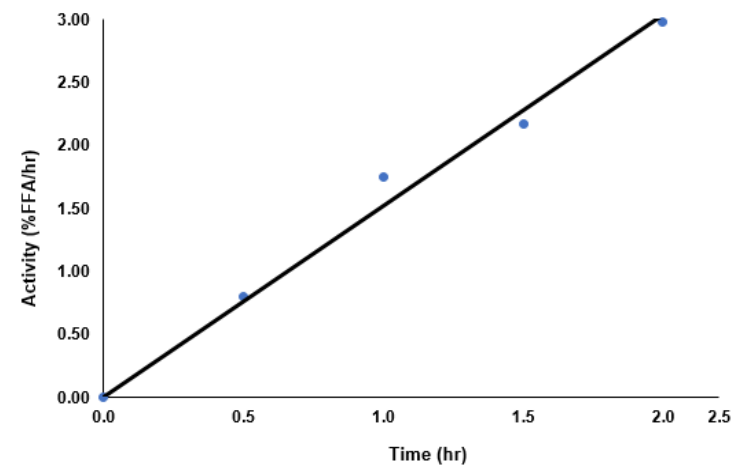

Fig 2: Effect of time on lipase activity (\%FFA/hr)

The effect of varying period of incubation on lipolysis is shown in Fig 2. A linear, logarithmic relationship was observed between reaction time and rate of lipolysis. The optimal activity was found to be at $2 \mathrm{hr}$ of incubation. This trend could be attributed to zeroorder reaction, indicating that the substrate is not limiting and that the products of hydrolysis exhibit no inhibitory action. Fig 3 shows the effect of $\mathrm{pH}$ on the activity on the lipase from sprouted melon seeds. The optimum $\mathrm{pH}$ for this lipase is at $\mathrm{pH}$ 5.0. This implies that the lipase is optimally active at acid $\mathrm{pH}$. Some other lipases have been found to be optimally active at acidic $\mathrm{pH}$. For example, $\mathrm{pH}$ 5.0. for germinated castor bean lipase (Org et al., 1985) and pH 4.2 for Oil Palm mesocarp lipase (Abigor et al., 1985). However, optimal lipase activity for some other seeds have been observed at near neutrality for Pentaclethra lipase (Enujiugha et al., 2004) pH 7.5 for lipase from Jatropha curcas L. (Abigor et al., 2002) and pH 8.5 for peanut alkaline lipase (Sanders and Pattee, 1975). The lipase activity was found to decrease steadily from $\mathrm{pH}$ 7.0 to $\mathrm{pH} 10.0$. This suggests that the enzyme was lost due to inactivation at this alkaline $\mathrm{pH}$. The effect of different amount of substrate on the activity of the melon seed lipase is represented in Fig 4. Rate of lipolysis was observed to increase linearly at amounts up to $5.0 \mathrm{~g}$. At higher amount of substrate, there was a drop in the rate of lipolysis though increase in activity was meagre i.e. no apparent decline in the activity of the enzyme. At this stage, increasing the concentration does not produce a concomitant increase in the rate of the reaction. Furthermore, the lipase was found to possess a $\mathrm{K}_{\mathrm{m}}$ of $6.25 \mathrm{~g}$ of RBD palm oil and a $\mathrm{V}_{\max }$ of $13.33 \% \mathrm{FFA} / \mathrm{hr}$ (Fig 5). These values suggest that the enzyme has a moderate to low affinity for its substrate (RBD palm oil) and the maximum activity that can be exhibited by the lipase is $13.33 \%$ FFA/hr.

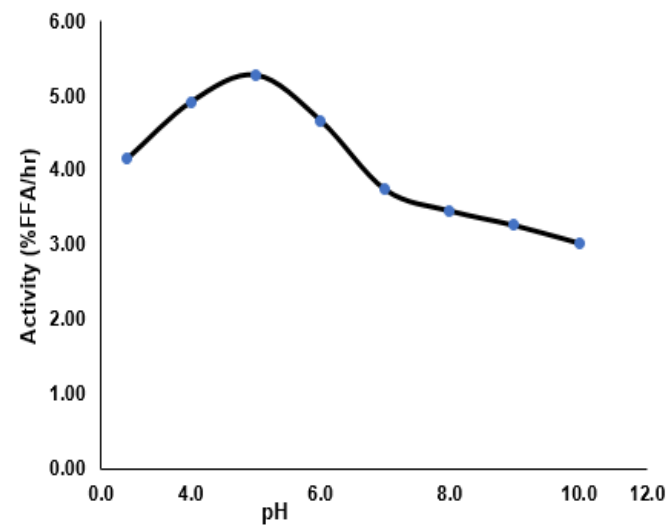

Fig 3: Effect of $\mathrm{pH}$ variation on lipase activity (\%FFA/hr)

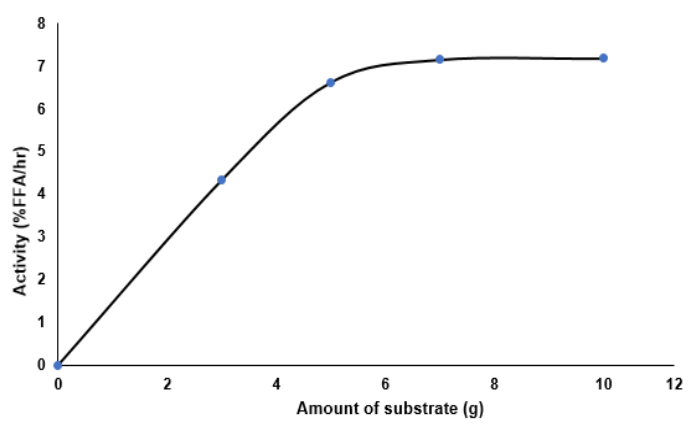

Fig 4: Effect of varying amount of substrate (g) on lipase activity (\%FFA/hr)

Table 2 summarizes the results of the American Society of Test materials and methods on RBD palm oil and its methyl ester (biodiesel). The RBD palm oil methyl ester (biodiesel) had a density of $0.87 \mathrm{~g} / \mathrm{mL}$, cloud point of $22^{\circ} \mathrm{C}$, pour point of $12^{\circ} \mathrm{C}$ and a relative density of 0.884 . The cloud and pour point are both cold temperature properties of alkyl esters (biodiesel). The cloud point does not meet the acceptable specification of United States prepared biodiesel of between $9-15^{\circ} \mathrm{C}$ for ethyl tallow, isobutyl ester tallow with a cloud point of $17^{\circ} \mathrm{C}$ and methyl ester tallow with a cloud point of $8^{\circ} \mathrm{C}$ (Foglia et al., 1997). It is also inferior to the Palm oil methyl ester of Brazilian origin with a cloud point of $13^{\circ} \mathrm{C}$ and methyl ester of Peanut oil of $5^{\circ} \mathrm{C}$ (Pischiger et al., 1982). The pour point of $12^{\circ} \mathrm{C}$ observed for RBD palm oil methyl ester (biodiesel) meets the Malaysisan specification $\left(12^{\circ} \mathrm{C}\right)$ (Henshaw, 1990) but does not meet the Austrian specification for diesel $\left(-6^{0} \mathrm{C}\right)$. 


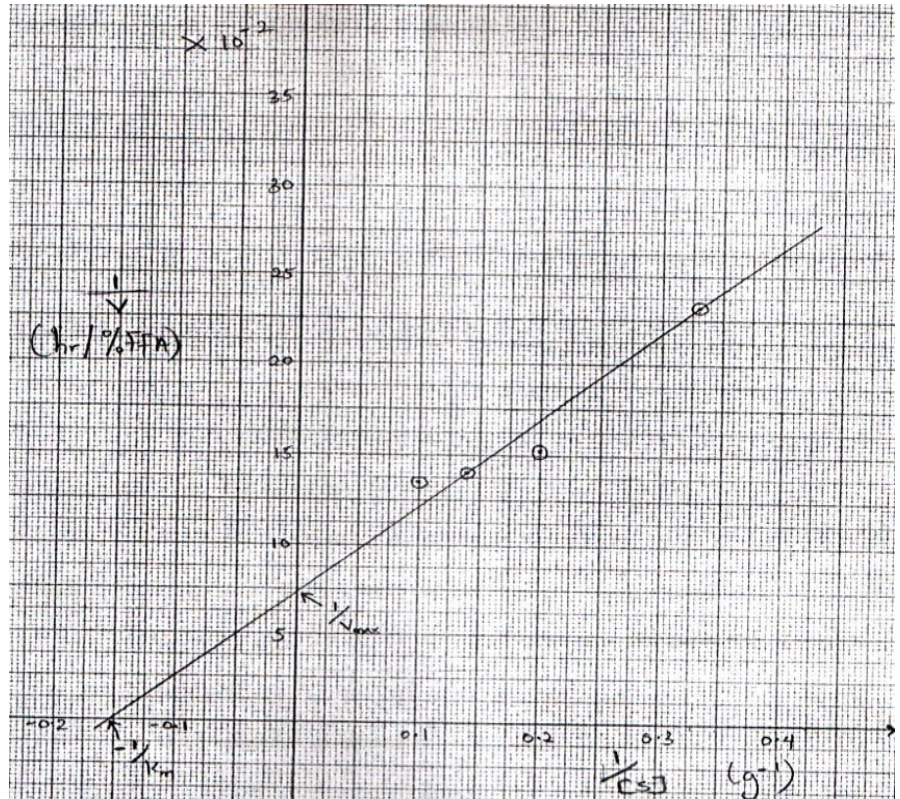

Fig 5: Lineweaver-Burk (Double-reciprocal) plot for determination of $V_{\max }$ and $K_{m}$ of the crude lipase

Table 1: \% composition of transesterification product

\begin{tabular}{llllll}
\hline Alkyl ester & FFA & TAG & 1,3-DAG & 1,2-DAG & MAG \\
\hline 0.61 & 0.81 & 93.17 & 4.15 & 1.26 & 0 \\
\hline
\end{tabular}

Table 2: Some fuel properties of RBD palm oil and biodiesel

\begin{tabular}{lccccc}
\hline & Density $(\mathbf{g} / \mathbf{m L})$ & \%FFA & Cloud point $\left({ }^{\mathbf{0}} \mathbf{C}\right)$ & Pour point $\left({ }^{\mathbf{0}} \mathbf{C}\right)$ & Relative density \\
\hline RBD Palm Oil & 0.877 & 1.546 & 24 & 18 & 0.89 \\
Biodiesel & 0.8702 & 1.408 & 22 & 12 & 0.884 \\
\hline
\end{tabular}

Conclusion: The results from this research shows an active lipase (acetone powder) has been isolated from sprouted melon seeds (Cucumeropsis mannii). The optimum time of lipolysis was found to be $2 \mathrm{hr}$ incubation time with a pH optimum of 5.0. Lipolysis was achieved optimally at $2.0 \mathrm{~g}$ amount of enzyme. The velocity (activity) of the enzyme was half-maximal $(\mathrm{Km})$ when the amount of substrate was $6.25 \mathrm{~g} \mathrm{RBD}$ palm oil while its maximum velocity (Vmax) was $13.33 \%$ FFA/hr. The cloud and pour points of the RBD palm oil methyl ester prepared with the lipase was $220 \mathrm{C}$ and $120 \mathrm{C}$ respectively. These values do not meet the standard specifications. Furthermore, the methyl esters had a density of 0.8702 $\mathrm{g} / \mathrm{mL}$ and a relative density of 0.884 . The result of the HPLC analysis showed that only $0.61 \%$ of the starting material was converted to the methyl esters (biodiesel) due to the unfavourable viscosity conditions which affected the intimate mixing of the substrate with lipase as well as inactivation by denaturation, due to the loss of water of hydration. In order to be used industrially, better reaction conditions (e.g. type of co-substrate) need to be established for the lipase.

Acknowledgements: The authors wish to acknowledge the support of late Dr Abigor, RD, Dr Obibuzor, JU and all lab members of the Biochemistry Division, NIFOR, for their assistance throughout the period of this research.

\section{REFERENCES}

Abigor, RD; Okpefa, E; Bafor, ME; Uadia, PO; Osagie, AU (1985). Partial purification and some properties of the lipase present in oil palm (Elaesis guineensis) mesocarp. J. Sci. Food Agric. 36: 599 - 600.
Abigor, RD; Uadia, PO; Foglia, TA; Haas, MJ; Jones, KC; Okpefa, JU; Obibuzor, JU; Bafor, ME (2000). Lipase-catalyzed production of biodiesel fuel from some Nigerian Lauric oils. Biochem. Soc. Trans. 28(6): $979-981$.

Abigor, RD; Uadia, PO; Foglia, TA; Haas, MJ; Scott, K; Savary, BJ (2002). Partial purification and properties of lipase from germinating seeds of Jatropha curcas L. J. Am. Oil. Chem. Soc. 79: 1123 - 1126.

Achu, MB; Fokou, E; Tchiégang, C; Fotso, M; Tchouanguep, FM (2005). Nutritive value of some Cucurbitaceae oilseeds from different regions in Cameroon. Afr. J. Biotechnol. 4: 1329 - 334.

Achu, MB (2006). A Study of some Physicochemical Characteristics and Nutritional Properties of Five Cucurbitaceae Oilseeds from Cameroon. Thesis presented and defended for the award of a Doctorate $\mathrm{PhD}$ in Biochemistry. Faculty of Science, University of Yaounde. Pp. 180

Cvengros, J; Cvengrosova, Z (1994). Quality Control of Rapeseed Oil Methyl Esters by Determination of Acyl Composition. J. Am. Oil Chem. Soc. 71:13491352.

Edmundo, C; Valerie, D; Didier, C; Alain, M (1998). Efficient lipase-catalyzed production of tailor-made emulsifier using solvent engineering coupled to extractive processing. J. Am. Chem. Soc. 75: $309-313$. 
Enujiugha, VN; Thani, FA; Sanni, TM; Abigor, RD (2004). Lipase activity in dormant seeds of the African oil bean (Pentaclethra macrophylla Benth). Food Chem. 88: 405 -410.

Fokou, B; Achu, MB; Chaungues, TM (2004). Preliminary nutritional evaluation of five species of egusi seeds in Cameroon. Afr. J. Food Agric. Nutr. Dev. 4: $8-14$

Foglia, TA; Nelson, LA; Dunn, RO; Marmer, WN (1997). Low temperature properties of alkyl esters of tallow and grease. JAOCS. 75(8): $951-955$.

Graboski, MS; McCormick, RL (1998). Combustion of fat and vegetable oil derived fuels in diesel engines. Prog. Energy Combust. Sci. 24: 125 - 164.

Gandhi, NN (1997). Application of lipase. JAOCS 74(6): $621-633$.

Gwanfogbe, RN; Chambers, NE, Martin, G; Fotso, M; Smith, MF (1991). Comparison of the acceptability of traditional Cameroon sauces made with addition of oilseed to improve nutritional value. Eco. Food Nutri. 25: 323 - 332.

Haas, MJ; Cichowicz, DJ; Bailey, DG (1992). Purification and characterization of an extracellular lipase from the fungus Rhizopus delemar. Lipids 27: $571-576$.

Hassanien, FR; Mukherjee, KD (1986). Isolation of lipase from germinating oilseeds for biotechnological processes. J. Am. Oil Chem. Soc. 63(7): 893 - 897.

Henshaw, AWE (1990). Experience with alternative fuels for small stationary diesel engines. Proceeding of the International Seminar of fuels for automotive and industrial diesel engines. Institute of Mechanical Engineers, London. Pp 117 - 122.

Hills, G, (2003). Industrial use of lipases to produce fatty acid esters. Eur. J. Lipid Sci. Technol. 105: 601 - 607

Huang, SHC (1975). Enzymes of glycerol metabolism in the storage tissues of fatty seedling plant. Plant physiol. 55: $555-558$.

Hulton, D; Strumpf, PK (1969). Characterization of the B-oxidation systems from maturing and germinating castor bean seeds. Plant physiol. 44: 408 - 519.

Khor, HT; Tan, NH; Chua, CL (1986). Lipase-catalyzed hydrolysis of palm oil. J. Am. Oil Chem. Soc. 63(4): $538-540$.

Kumar, A; Gross, RA (2000). Candida Antarctica lipase B catalyzed transesterification: New synthetic routes to copolymers. J. Am. Chem. Soc. 122: $11767-$ 11770.
Lin, YH; Huang, AHC (1983). Lipase in lipid bodies of cotyledons of rape and mustard seedlings. Arch Biochem. Biophys. 225:360 - 369.

Martin, F (1998). Curcubit seeds as possible oil and protein sources for small scale household use in the hot humid tropics. Oil Crops Processing 4: 2 - 7 .

Muto, S; Beevers, H (1974). Lipase activities in castor bean endosperm during germination. Plant Physiol. 3: $277-293$

Nelson, LA; Foglia, TA; Marmer, WN (1996). Lipasecatalysed production of biodiesel. JAOCS. 73(8): $1191-1195$

Noureddini, H; Harkey, D; Medikonduru, V. (1998). A continuous process for the conversion of vegetable oils into methyl esters of fatty acids. J. Am. Chem. Soc. 75 : 1775

Org, RL; st. Angelo, AJ; Alschul, AM (1985). The acid lipase of the castor bean: properties and substrate specificity. Biochem. J. 3: $99-105$.

Pirozi, D (2003). Improvement of lipase stability in the presence of commercial triglycerides. Eur. J. Lipid Bci. Technol. 105 (11): 608 - 613.

Pischiger, GH; Pakon, AM; Siekman, RW, Fernardes, FR (1982). Methyl esters of plant oils as diesel fuels, either straight or in blends. In: Proceedings of the International Conference on plants and vegetable oils. Am. Soc. Agric. Eng. (ASAE) pub. 4-82. St Joseph Pp. 198 - 200.

Ponka, R; Fokou, E; Fotso, M; Achu, MB; Tchouanguep, FM (2005). Methods of preparation and the energy, protein and mineral values of three Cameroonian dishes: "Corn chaff", "nnam owondo/ebobolo" and "nnam ngon/ebobolo". Afr. J. Food Agric. Nutr. Dev., 5: 1 - 12 .

Sanders, TH; Pattee, HE (1975). Peanut alkaline lipase. Lipids 10(1):50 - 54 .

Wetter, LR (1957). Some properties of the lipase present in germinating rapeseed. J. Am. Oil Chem. Soc. 34: $66-70$. 